TITLE:

\title{
Significance of Central Noradrenergic System on Harmaline Induced Tremor( Abstract_要旨)
}

$\operatorname{AUTHOR}(S)$ :

Yamazaki, Masakazu

\section{CITATION:}

Yamazaki, Masakazu. Significance of Central Noradrenergic System on Harmaline Induced Tremor. 京都大学, 1979, 医学博士

ISSUE DATE:

1979-05-23

URL:

http://hdl.handle.net/2433/222183

RIGHT: 


\section{【119 】}

氏 名 㟧崎正寿

学位の種類医学 博士

学位記番号。医 博 第 529 号

学位授与の日付”昭 和 54 年 5 月 23 日

学位授与の要件 学 位 規 則 第 5 条第 1 項 該 当

研究科. 専攻医学研究科生理系専 攻

学位論文題目 Significance of Central Noradrenergic System on

Harmaline Induced Tremor

(ハルマリン誘発性振戦に抢ける中枢ノルアドレナリン系の意義）

論文調査委員教授藤原元始 教 授佐々木和夫 教授高折修二

\section{論 文内容の要旨}

パーキンソン病は, 振戦, 筋硬直, 無動症など錐体外路系症状を主徵とする疾患であり, 黒質一線条体 ドーパミン性神経系の変性と共に, 青斑核を含む中枢ノルアドレナリン性神経系の広範な変性が認められ ている。この青斑核に由来する中枢ノルアドレナリン性神経終末は，錐体外路系を含む中枢神経系の広い 領域に分布して和り，パーキンソン病患者では，皮質下に括けるノルアドレナ゙リン含量の減少が報告され ている。本論文では，パーキンソン病椂振戦の実験モデルとしてハルマリン誘発振戦を用い，青斑核由来 のノルアドレナリン性神経系が，振戦発生機構にいかなる役割を演じているかる研究したものである。

実験は一定室温と食慨によって飼育された雄性成熟ラットを用い,ノルアドレナリン前駆アミノ酸であ るLースレオ-3,4-ジヒドロフェニールセリン (L-DOPS) 牤よびノルアドレナリンの側脳室内投与, 両側 青斑核の電気的刺激，両側青斑核の電気的破壊および6ーヒドロキシドーパミン (6-OHDA) 注入による 化学的破壞などの前処置を行い, ハルマリン誘発振戦の強度, 持続時間怙よび筋電図の測定を行った。ま た, 脳内ノルアドレナリン量は螢光法にて測定し, 刺激特よび破壞部位の範囲は螢光組織化学法により確 認した。

ハルマリン投与 $5 \sim 10$ 分後より筋電図上に $10 \sim 12$ 回/秒の振戦波が出現し, 振戦の強さ, 発生頻度およ び持続時間は投与量に比例して増加した。ハルマリン $10 \mathrm{mg} / \mathrm{kg}$ 腹腔内投与により全例に振戦が発現し,

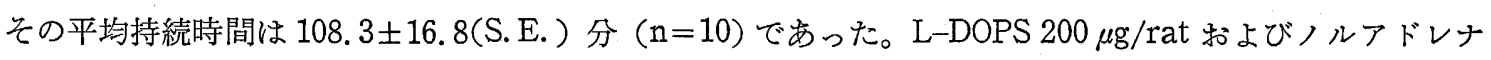
リン $50 \mu \mathrm{g} / \mathrm{rat}$ の脳室内前投与によりハルマリン $10 \mathrm{mg} / \mathrm{kg}$ 誘発振戦の持続時間は 40〜 $45 \%$ 有意に短縮 乙, 同時に大脳皮質, 線条体などのノルアドレナリン量の著しい增加がみられた。また, 両側青斑核の頻 回刺激により $(4 \mathrm{~V}, 30 \mathrm{~Hz}, 2$ 分), 筇電図上の $10 \sim 12$ 回/秒のハルマリン誘発振戦波は明らかに抑制さ れた。これらの結果は, 青斑核由来ノルアドレナリン性神経系の活動立進がハルマリン誘発振戦を抑制す ることを示している。一方, 両側青斑核を電気的に, または 6-OHDA にて化学的にほとんど完全に破壞 した動物ではハルマリン誘発振戦の持続時間は約 $60 \%$ 有意に延長し, 同時に大脳皮質招よび線条体のノル 
アドレナリン量は著しく減少した。また, 螢光組織学的に青斑核のノルアドレナリン含有細胞数の著減括 よび神経線維に沿った螢光の蓄積がみられた。これらのことは青斑核由来ノルアドレナリン性神経系の活 動低下がハルマリン誘発振戦を増悪することを示している。

従来, ハルマリン誘発振戦は, 脳内ドーパミン, セロトニン, 特よびアセチルコリン系機能の不均衡に よるといわれ，ノルアドレナリン系の関与については明らかでなかった。本論文は，青斑核のノルアドレ ナリン系がハルマリン誘発振戦に対し，㧕制性に作用することを明らかにしたものであり，このことは中 枢ノルアドレナリン性神経系が, パーキンソン病の振戦発生機構に関与するといわれている線条体, 下オ リーブ核，小脳などに投射し，それらの部位を介して振戦の発現に抑制的な役割を演じているものと考兄 られる。

\section{論文審查の結果の要旨}

パーキンソン病では黒質一線条体ドーパミン性神経系の変性と共に, 青斑核を含む中枢ノルアドレナリ ン性神経系の変性が認められている。

本研究はパーキンソン病様振戦の実験モデルとしてラットのハルマリン誘発振戦を用い，中枢ノルアド レナリン性神経系が振戦発生機構にいかなる役割を演じているかを調べたものである。ノルアドレナリン およびその前駆アミノ酸であるLースレオ-DOPS の脳室内投与，扣よび両側青斑核の頻回電気刺激はハル マリン誘発振戦を明らかに抑制した。一方，両側青斑核を電気的に，または6ーヒドロキシドーパミンに より化学的に破壊した動物では，大脳皮質および線条体のノルアドレナリン量の著しい減少と同時に，八 ルマリン誘発振戦の持続時間を有意に延長した。従って，青斑核由来の中枢ノルアドレナリン性神経系は ハルマリン誘発振戦に対し抑制的に作用すると結論された。以上の研究は振戦発生機構に関与する中枢ノ ルアドレナリン性神経系の役割について有意義な新知見を加えたものである。

よって, 本論文は医学博士の学位論文として価値あるものと認める。 